\title{
DIE STUDIE VAN DIE GODSDIENS
}

\author{
deur \\ Prof. F. J. vaN ZYL
}

Die Godsdienswetenskap bestudeer die godsdiens, die hole wêreld van die godsdiens, die konkrete, empiriese godsdienste: alles wat eens godsdiens geheet het en die godsdiens in sy verskyningsvorme vandag. Dis nog maar 'n betreklike jong wet?nskap, die Godsdienswetenskap. As kind van die Verligting is hy gebore uit die studie van die Oosterse tale, kulture en godsdienste, 'n studie wat in die $18 \mathrm{de}$ eeu begin opbloei het, met die groot filoloog Max Müller as die eerste beoefenaar van hierdie wetenskap. In 1856 verskyn sy "Comparative Mythology" en in 1870 'n "Introduction to the science of religion" wat in 1878 gevolg word deur sy lesings oor "Origin and growth of Religion as illustrated by the Religions of India". In lg. werk verdedig Müller die standpunt dat die Vediese literatuur nie alleen die oudste oorkonde van die mensheid is nie, maar ook die oorsprong van alle godsdiens. Hierdie opvatting is deur latere ondersoek weerlê, maar die publikasie deur Müller van die Heilige Boeke van die Ooste, sal altyd aangeteken bly staan as een van sy grootste prestasies.

Toe die teologiese fakulteit Afdeling A in 1917 aan die destydse T.U.K. gevestig is, was die Godsdienswetenskap 'n vak wat maar pas toegang gekry het tot die Europese Universiteite. In Duitsland het dit so laat as 1910 eers gebeur. 'n Verdere saak van belang i.v.m. die erkenning van hierdie wetenskap as waardige gebied van akademiese ondersoek en onderrig, is dat dit in slegs weinige universiteite ' $n$ plek en onderdak in die teologiese fakulteit gevind het. Aan die Universiteit van Pretoria het die Godsdienswetenskap sy plek in die teologiese fakulteit gekry met die instelling van 'n selfstandige departement in 1935, nadat in die voorafgaande jare wel in sekere godsdienswetenskaplike vakke gedoseer is. In die nuwe departement is die volgende vakke gedoseer: Godsdiensgeskiedenis, Fenomenologie van die Godsdiens, Godsdienspsigologie en Godsdiensfilosofie. Van hierdie vakke het een, die Godsdienspsigologie, sedert die instelling van hierdie departement, verdwyn, aangesien dit verskuiwe is na die Praktiese Teologie en wel onder die nuwe naam van Pastorale Psigologie. Hoewel met liefde en toewyding beoefen, was dit 'n vak wat van die begin af op 'n verkeerde spoor geraak 
het, deurdat dit te veel gerig was op 'n psigologiese verklaring van die godsdiens en te min op die mens as voorwerp van die pastorale sorg van die kerk. Met die nekslag wat alle verrassionalisering, etisering en psigologisering van die geloof deur die Dialektiese Teologie toegedien is, het die Godsdienspsigologie opgehou om te bestaan en moes hy plek maak vir die Pastorale Psigologie wat nie die godsdiens psigologies wil verklaar nie, maar psigologiese hulpdiens wil verrig aan die pastor in die sielsorg.

Die Godsdiensgeskiedenis en Fenomenologie van die Godsdiens wat die godsdiens in sy historiese en strukturele verskyningsvorme bestudeer, het wat inhoud en metode betref deur die jare weinig verander. Die krities-wetenskaplike ondersoek wat met nougesette ywer volgehou is op hierdie twee gebiede het tot indrukwekkende resultate gelei en ons feitlike kennis van en insig in die realiteit van die godsdiens op merkwaardie wyse vergroot. In die afgelope vyftig jaar het die ondersoek van die vroegste kultuur van die Nabye Ooste, Indië, Oos-Afrika, Afrika en Europa veral groot vooruitgang gemaak. Daar is geen godsdiens meer waarvan die historiese ontwikkeling nie verhelder is deur 'n geslag van ondersoekers wat deeglik geskool is in die tegniek van historiese ondersoek nie. Baie publikasies oor die godsdienste van die wêreld, gesamentlik of afsonderlik, het gereeld verskyn en verskyn nog voortdurend. Daar is vandag ook veral 'n besondere groot vraag by die algemene leserspubliek na informasie oor die vreemde. godsdienste en die verhouding van die christendom tot hulle.

Sedert Chantepie de la Soussaye 'n hoofstuk aan die Fenomenologie van die Godsdiens gewy het in sy "Lehrbuch der Religionsgeschichte" in 1887, het hierdie tak van die godsdienswetenskaplike ondersoek voorspoedig ontwikkel en ook ryke vrug gelewer. Daar het ook verdieping gekom in die ontwikkeling en ontplooiing van hierdie vak wat 'n leer wil bied oor die godsdienstige verskynsels. Waar Chantepie slegs 'n beskrywing van die verskynsels wou gee, stel niemand hom meer vandag daarmee tevrede nie. Manne soos Otto, van der Leeuw, Söderblom en Wach, wil nie net beskryf nie, maar verstaan. En volgens die fenomenologiese metode wat van Hussierl afkomstig en ontwikkel is, wil hulle die godsdienstige verskynsel uit homself verstaan en ken. Daarom wil die fenomenologie beskryf wat is, soos dit is, sonder enige spekulatiewe bymengsel. 'n Hooggewaardeerde beginsel by die studie van die godsdienste, hoewel soms eensydig oordryf; was nog altyd die sg. onvooringenomen- 
heid. Die tegniese uitdrukking vir die besondere benaderingswyse is die epoché, wat daarop neerkom dat die ondersoeker sonder enige vooroordeel sy objek moet nader, alle vrae betreffende die waarheid en die waarde van 'n varskynsel moet uitsluit, om sodoende die hoogste mate van objektiwiteit te ber-ik, wat dikwels sinoniem met wetenskaplikheid beskou is. Hierdi2 wetenskapsideaal van die godsdienswetenskap kan histories verklaar word as in ag geneem word dat dit 'n kind van die Verligting was wat die positiwistiese wetenskapsbegrip veral hoog waardeer het. Ons het reeds gesien dat dit in die Godsdiensfenomenologie om die verstaan van die godsdiens gaan, en dit is dieselfde as interpretasie, en dit is weer nie bloot 'n verstandelike aangeleentheid nie, want die mens met sy hele bestaan is daarby betrokke. 'n Mens kan nie in so 'n onderneming batrokke wees los van die bestaanssituasie waarin jy verkeer en die hele bodem van oortuigings waarin jou lewe gegrond is nie. Vandag weet ons dat die hooggeroemde ideaal van absolute objektiwiteit slegs ' $n$ fiksie is. Al die ondersoekers wat hierdie ideaal verdedig het, het tog bewus of onbewus hulle ondersoek met bepaalde vooroordele onderneem. En omdat dit so is, bestaan daar geen rede waarom 'n mens nie bewus van sekere vooronderstellings sal uitgaan by die studie van die godsdiens nie. 'n Mens hoef ook nie jou teologiese vooronderstellings onder stoele en tafels weg te steek nie, maar as teoloog jou ook met 'n skoon gewete aan die bestudering en interpretasie van die godsdiens wy, mits jy natuurlik die reëls van hierdie spel in ag neem en jou feite so onpartydig as moontlik behandel. Die beste waarborg teen vooroordeel by die bestudering van die godsdiens is dat ' $n$ mens sonder om te skroom uitkom vir jou oortuigings en vooronderstellings, want deur dit suiwer te stel staan 'n mens in dieselfde posisie as enige ander sg. objektiewe ondersoeker van die godsdiens wat heel dikwels onbewus tog van sekere vooronderstellings uitgegaan het. 'n Objektiwiteit soos hierdie laaste moet gelykgestel word aan persoonlike willekeur, wat ten sterkste verwerp moet word by wetenskaplike ondersoek van watter aard ookal. Dat die eis van objektiwiteit nie sonder betekenis was vir die ondersoek van die godsdiens nie, en dat dit 'n baie bruikbare metode is, het die skitterende resultate wat gelewer is wel genoegsaam bewys. Solank maar net onthou word dat dit nie die enigste metode is nie.

Die fenomenologiese ondersoekmetode is filosofies van aard insoverre, soos ons gesien het, hy hom rig na die hooflyne van die beskouing van Husserl. Sy oogmerk is om die diepste 
kern van die saak van die godsdiens te begryp. Om hierdie rede het die Godsdiensfolisofie, soos dit in die vorige eeu beoefen is, ook nie meer reg van bestaan en bestaansmoontlikheid oorgehou nie, omdat sy werksaamhede grotendeels deur die Fenomenologie van die Godsdiens oorgeneem is. Hierdie vierde vak van die Departement Godsdienswetenskap het dan ook gedurende die afgelope vyftig jaar 'n radikale verandering ondergaan wat sy $\sin$ en bedoeling, taak en vooronderstellings betref. Ons wil hierdie verandering nou verder in besonderhede nader betrag.

'n Jaar of twee na die stigting van die teologiese fakulteit aan die Universiteit van Pretoria het „Der Römerbrief” van Karl Barth verskyn. Sedert hierdie man op die teologiese toneel verskyn het, en met hom 'n nuwe teologie, het ,godsdiensfilosofie" 'n swaarbelaste woord en begrip geword in die Protestantse teologie, sowel wat die inhoud as die naam van hierdie vak betref. Hierdie woord wek onaangename assosiasies en die rede daarvoor lê in die feit dat dit die Protestantse teolodie herinner aan 'n tyd van groot dwaling en vergissing t.o.v. sy eie grondslag, inhoud en norm, en as gevolg daarvan ook aan 'n tyd van smadelike afhanklikheid en ondergeskiktheid aan die filosofie. Ook die teologie het in die 19de eeu so onder die bekoring gekom van die positiwistiese wetenskapsbegrip van die Verligting, dat hy bereid was om sy eie grondslag te verlaat, die nuwe wetenskapsideaal te aanvaar, en self godsdienswetenskap i.p.v. godgeleerdheid te word. Godsdiensfilosofie het die belangrike vak in die teologiese fakulteit geword.

Agter die opkoms van die 19de eeuse godsdiensfilosofie lê 'n lang geskiedenis van teologiese verval. Dit het reeds in die $18 \mathrm{de}$ eeu begin en dit word die duidelikste sigbaar in die ortodokse skrifbeskouing. As Brunner hierdie verval nagaan in sy „Religionsphilosophie evangelischer Theologie”, merk hy op dat die Reformatoriese skrifbeskouing in sy teendeel deur die ortodoksie omvorm is, sonder dat dit agtergekom is. Vir die Reformatore is die Bybel die getuienis van die godsopenbaring. Die skrifwoord is 'n mensewoord waardeur die Godswoord tot ons kom. Daar is dus 'n identiteit, 'n gelykheid van Godswoord en skrifwoord, maar geen direkte identiteit, sodat Godswoord en skrifwoord sonder meer gelyk is nie. Dis 'n indirekte identiteit wat bewerk word deur die getuienis van die Heilige Gees, 'n identiteit wat dus alleen werklik is in die paradoks van die geloof. Die ortodoksie het die indirekte identiteit in ' $n$ direkte verander. Openbaring, bekendmaking van God, was nie meer die gebeurtenis waardeur die getuienis van die Heilige Gees die 
sprekende stem van God in die skrifwoord laat hoor het nie, en waardeur God self die mensewoord van die Skrif vir Sy Woord in diens neem nie. Openbaring as 'n aktuele gebeurtenis is verander in 'n statiese geopenbaarheid, 'n openbaring dus wat altyd reeds voor hande en direk toeganklik is. In die plek van die aktuele openbaringsdaad van God, is die Bybelboek gestel wat op homself waar is, en waarvan 'n mens eiemagtig, sonder die getuienis van die Heilige Gees kan sê dat dit die W.oord van God is. Openbaring wat alleen 'n werklikheid is in die wondergebeure wanneer de persoonlike God hom sprekend wend tot die mens, het nou 'n onpersoonlike, Gees-lose algemene gegewenheid geword en 'n algemene waarheid wat rasioneel vasgestel kan word. Die Bybel het nou 'n heilige ding geword, 'n openbaringsdraer. Hoe noodlottig so 'n skrifbeskouing vir die christelike teologie is, het spoedig geblyk toe die natuurwetenskaplike ondersoek die rasionalistiese bybelvesting van die ortodoksie in duie laat stort het. Kopernikus en Gallileo het die Bybelse chronologie, die geskiedswetenskap en die literêre kritiek die onfeilbaarheid van die Bybel as menseboek omvergewerp. Die gesag van die Skrif was daarmee heen en die laaste waarborg vir waarheid is in die onfeilbare verstand van die mens gevind. 'n Nuwe teologie het ontstaan, nie meer gegrond op die openbaring van God waarvan die Bybel die outentieke getuienis is nie, maar gebou op 'n algemene, rasionalistiese openbaringsbegrip en 'n algemene godsdiensbegrip, waarvan die christelike openbaring en geloof slegs ' $n$ bepaalde gestalte en uitingsvorm was.

Die heersende godsdiensfilosofie van die 19de eeu het ook hierdie gees geadem. In die teologie of godsdiensfilosofie het dit nie meer om die Bybelse openbaring gegaan nie, maar om die begrip godsdiens. Christelike teologie het hom besig gehou met die christelike godsdiens as bepaalde uitingsvorm van die algemene godsdiens. Een van die belangrikste doelstellings van die 19de eeuse godsdiensondersoekers was om 'n verklaring van die godsdiens te gee. Daar is begin met 'n natuurlike, d.w.s. 'n verklaring uit die menslike bewussyn self. Allerlei teorieë oor die ontstaan en ontwikkeling van die godsdiens het die lig gesien, soos die animistiese van Tylor, die mana-teorie van Codrington en die psigologiese van Freud. Teenoor hierdie naturalistiespsigologiese verklarings staan die transcendentaal-filosofiese van James en Otto waar die godsdiens as noodsaaklike uiting van die mensegees gesien word en godsdiens die terrein is waar die mensegees in aanraking kom met die absolute, die transcendente, die goddelike, terwyl hierdie absolute of in die wil, of 
in die gevoel, of in die rede gevind word. So omskrywe Kant die godsdiens as die opvat van alle pligte as goddelike gebooie; vir Schleiermacher is die wese van die godsdiens geleë in die gevoel van eenheid met die oneindige; vir Hegel is godsdiens die betrokkenheid van die eindige gees op die absolute Gees.

Kenmerkend van die laaste drie voorbeelde van godsdiensverklaring is dat die christendom steeds beskou word as die hoogste uittingsvorm van die godsdiens as sodanig. In hierdie tipe van godsdiensfilosofie word die godsdienste almal in een lyn gestel en met mekaar vergelyk, terwyl 'n sekere ontwikkeling van laer na hoogste aanvaar word. Hier word 'n rangorde van godsdienste opgestel en dit veronderstel 'n maatstaf waarvolgens die rangorde geskied. Die vraag is waar hierdie maatstaf vandaan kom en of hy as geldend aanvaar kan word. Die maatstaf wat as prinsiep vir die ordening aanvaar is, was die omvattende term: wese van die godsdiens. Die godsdiensfilosofie het hierdie wese uit die konkrete godsdienste afgelei. Die beskouing was so: daar is een algemene wese van die godsdiens wat in verskillende gestaltes tot uiting kom in die verskillende godsdienste van die wêreld. Die primêre taak van die godsdiensfilosofie was om hierdie algemene wese van die godsdiens vas te stel. Binne en van sekondêre betekenis in hierdie godsdiensfilosofies bepaalde wese van die godsdiens, kry die christelike teologie dan ook sy afgebakende terrein van werksaamheid. Hy moet hom besig hou met die christelike godsdiens as een van die besondere uitings en gestaltes - volgens Troeltsch tot hiertoe die hoogste uiting - van die algemene wese van die godsdiens. In kort kom dit daarop neer dat die christelike teologie op die godsdiens gefundeer word, en dat so 'n godsdiensfilosofie die christelike geloof, waarvan die teologie die wetenskaplike vorm is, in 'n algemene religieuse bewussyn oplos. Geen wonder dat manne soos Barth en Brunner in radikale geloof. Die ortodoksie het die indirekte identeit in 'n direkte verset gekom het teen so 'n fundering van die teologie nie en 'n verbete stryd gevoer het vir die selfstandigheid van die teologie. Vir beide is godsdiens in sy diepste wese 'n menslike poging tot selfverlossing, selfregverdiging en selfheiliging, en derhalwe in sy eintlike strekking 'n dwaling, en alleen daarom is dit ondenkbaar om die teologie op die godsdiens te fundeer.

Bzhalwe dat daar tot dusver nog nie geslaag kon word om eenstemmigheid te bereik in die vasstelling van ' $n$ filosofies bepaalde wese van die godsdiens nie - en ook nooit geslaag 
sal word nie - moet bowendien ook vermeld word dat die christelike geloof nooit ingepas kan word in die filosofiese skema van 'n algemene wese van die godsdiens nie, sonder geweldpleging van sy mees wesenlike karakter. Die eenvoudige waarheid is dat die christelike geloof nie in die godsdiens gegrond is nie, maar in die openbaring van God in Jesus Christus, en daarom wil dit nie pas in die filosofiese idee van die godsdiens nie. Want dit gaan by die geloof in Jesus Christus ook nie om 'n idee nie, maar om die geloof in 'n persoon, wat as die inhoud van die evangelie 'n krag van God is wat elke idee laat oopbreek, en opbreek. Dis nie die godsdiens wat die geloof bepaal nie, maar die geloof bepaal die godsdiens. In kort, die christelike teologie is nie in die godsdiens gefundeer nie, maar in die openbaring as grond van die geloof. Teologie is net soos filosofie wel menslike denke, maar 'n denke vanuit en vanaf die openbaring as 'n na-denke van wat eerste gedink is, terwyl filosofie denke oor, denke gerig op 'n voorwerp is. Die teologie grond sy uitsprake in die openbaring en doen sy uitsprake in gehoorsaamheid aan die Skrifgetuienis; die filosofie grond syne in dic rede, gehoorsaam aan die logos van die rede.

In soverre die filosofiese denke dan gerig word op die verskynsel godsdiens, het ons te doen met 'n filosofiese godsdiensfilosofie. Kwalitatief is so 'n godsdiensfilosofie nie anders as enige soort filosofie nie. Nog die feit dat die filosoferende mens 'n christen is, nog die feit dat die denke op die godsdiens gerig is, maak so 'n godsdiensfilosofie anders as gewone filosofie. As in hierdie verband van godsdiensfilosofie gepraat word, vind die besondere kwalifikasie Godsdiensfilosofie sy grond bloot in die feit dat die filosofiese besinning op die besondere gebied van die godsdiens gerig is. Nou kan daar teen die bestaan en aansprake van so 'n godsdiensfilosofie nie beswaar wees nie, mits dit homself nie verhef tot die enigste moontlike opvatting oor wat godsdiensfilosofie is nie, en mits dit ook nie optree met die pretensie om teologie te wees of om die teologie aan hom ondergeskik te ag nie. Ongelukkig was dit die geval in die vorige eeu met rampspoedige gevolge vir die teologie. Deurdat die teologie hom te veel aan die vreemde invloed van die filosofie blootgestel het, en dit juis as gevolg van die verwaarlosing van sy teologiese uitgangspunt, het hy sy reg as teologie verbeur en is hy deur die filosofie tot 'n groot mate oorwoeker.

Die groot wending het gekom toe Barth en Brunner en later ook Gogarten begin het om met alle mag tot hulle beskikking die teologie te bevry van die fiolsofiese oorheersing en 
hom weer waarlik teologie te maak deur die openbaring van God in Jesus Christus, soos dit in die Heilige Skrif deur profete en apostels betuig word, te erken as die enigste grond, fondament, norm en inhoud van die teologie. Hierdie stryd om die herstel en bevryding van die teologie het nie plaasgevind sonder felle slae teen die godsdiensfilosofie van die 19de eeu nie. Ons kan sê dat die nekslag omstreeks 1927 toegedien is aan die 19de eeuse godsdiensfilosofie. In daardie jaar skryf Barth die volgende betêkenisvolle woord in sy „Die christliche Dogmatik im Entwurf": „om die teologie op die werklikheid van die godsdiens te fundeer, beteken om dit op die eiemag van die mens te fundeer, waarin God nie net ver bly nie, maar waarin die mens sy verwydering van God juis voltrek". Hierdie woorde het die einde beteken van 'n godsdiensfilosofie van die ou stempel. As die godsdiensfilosofie as vak sou wou bly voortbestaan, sou hy heeltemal onvorm moes word tot 'n teologiese vak. Hierdie omvorming was noodsaaklik as hy nog van betekenis vir die kerk wou bly. Emil Brunner is die man aan wie die eer toekom vir hierdie omvorming van die godsdiensfilosofie tot 'n noodsaaklike en erkende teologiese vak. Hy het die weg aangetoon waarlangs die nuwe godsdiensfilosofie kon ontwikkel en vandag na jare van stilstand besig is om te ontwikkel. Die stryd van Brunner om ' $n$ teologiese godsdiensfilosofie te fundeer sal in die geskiedenis van die Protestantse teologie seker altyd aangeteken bly staan as die grootste bydrae van hierdie hoogsbegaafde Switserse teoloog. In sy „Religionsphilosophie evangelischer Theologie" stel hy dit dat soos vir die teologie in die algemeen, dit ook vir 'n christelike godsdiensfilosofie op Protestantse bodem geld, dat sy vooronderstelling alleen die openbaring in Christus kan wees soos in die Skrif betuig, en dat sy historiese uitgangspunt slegs die klassiek geformuleerde Reformatoriese geloofsgetuienis kan wees. Een en ander oor hierdie vooronderstelling en uitgangspunt moet nader opgemerk word. Soos vir die teologie in die algemeen, geld dus ook vir die godsdiensfiolsofie in die besonder dat sy teologiese karakter gegrond is in die feit dat hy met die openbaring te doen het. Die openbaring is egter nie iets waaroor die mens beskik of waar hy beslag op kan lê nie. Dat die mens God in sy openbaring kan ken, is geen mensemoontlikheid nie, maar vrye gawe en genade van God wat in die openbaringsgebeure self aan hom geskenk word en wat geheel-en-al 'n geloofswerklikheid is. Geloof is die wyse waarop die Heilige Gees die openbaring van God 'n menslike ervaring maak, dit dus aan die mens toe-eien. Tussen openbaring en geloof bestaan daar dus ' $n$ baie noue betrekking. Die enigste manier waarop 
die godsdiensfilosofie van die openbaring kan uitgaan, is om hom op die standpunt van die christelike geloof te stel, omdat ons van die openbaring alleen kennis in die geloof kan hê.

'n Godsdiensfilosofie met so 'n vooronderstelling en uitgangspunt is dus nie filosofie nie, maar teologie, en volgens Brunner daardie deel van die teologie waar die gesprek vanuit christelike vooronderstellings en beginsels met die godsdiens en filosofie gevoer moet word.

Hoewel Barth geen „regulāre" godsdiensfilosoof is nie, het hy in sy monumentale K.D. tog ook 'n besondere bydrae gelewer om gestalte te gee aan 'n nuwe godsdiensfilosofie wat in ooreenstemming is met die nuwere teologiese insigte. As Barth in sy Kerklike Dogmatiek in voortdurende diskussie met die filosofie tree, en veral die fundamentele struktuurverskil tussen filosofie en teologie aantoon, lewer hy daarmee ' $n$ voortreflike voorbeeld van ware beoefening van godsdiensfilosofie. In hierdie verband moet ons wys op 'n briljante artikel van Barth wat in 1960 verskyn het in "Philosophie und Christliche Existenz" oor die verhouding tussen filosofie en teologie. Daarin toon hy aan dat teoloog en filosoof wel albei met dieselfde waarheid besig is omdat daar slesg een waarheid is, maar albei is nie op dieselfde wyse met die waarheid besig nie en daarom gaan hulle weë binne die een groot waarheid uitmekaar en moet die teoloog ten minste vir die filosoof sê waarom hy nie sy weg kan gaan nie. Op sigself beskou het teoloog en filosoof ook met dieselfde probleme te doen, met die verskil dat wat vir die teoloog die primêre is vir die filosoof die sekondêre probleem is, en omgekeerd. Die een waarheid waarmee teoloog en filosoof te doen het, het twee momente albei het te doen met die twe momente, die verskil lê egter daarin dat hulle in omgekeerde volgorde met hierdie momente te doen het. Die momente van die een waarheid word in die taal van die teoloog so aangedui, dat dit gaan om die verhouding van Skepper en skepsel. Van dieper en groter betekenis as die twee momente van die een waarheid, is die volgorde daarvan vir die teoloog. Die teoloog staan en val met die onomkeerbare volgorde van die Skepper na die skepsel. Hier kan die teoloog geen haarbreedte wyk sonder om daardeur sy posisie as teoloog in gevaar te bring nie. Die teoloog kyk en dink van die Skepper na die skepsel. Daar is vir die teoloog geen ander weg moontlik nie, want Christus wat in sy persoon self die weg en die waarheid is, kom van bo na onder en keer weer terug na bo. Hierdia weg kan nooit ommekeer word nie. As die teoloog teoloog wil 
bly, is hy aan hierdie weg gebonde en aan hierdie weg alleen. Daar is ' $n$ analogie in bemoeiing met probleme tussen filosoof en teoloog. Dit blyk ook uit die aanwending van terminologie. Teenoor die een begripspaar: Skepper en skepsel, het die filosofie 'n hele reeks, soos idee en werklikheid; logos en rede; transcendensie en eksistensie ens. Die filosoof se weg in die bemoeiing met die probleme waarmee die teoloog hom besig hou geskied egter in 'n ander volgorde as die van die teoloog. Die filosoof is op die weg van die skepsel na die Skepper, en vandaar weer terug na die skepsel as die voorwerp van sy primêre interesse. En juis hierdeur skei die weë van teoloog en filosoof.

Aangesien godsdiensfilosofie as teologiese vak geen filosofie is nie, en aangesien filosofie wesenlik verskil van teologie, kan die vraag ontstaan of "Godsdiensfilosofie" as naam vir hierdie tak van die trologiese wetenskap nog gehandhaaf kan word. As die teologie nie op die godsdiens gefundeer is nie en die christelike teologie nie daardie kerklike werksaamheid is wat hom spesifiek met die christelike godsdiens as uitingsvorm van die algemene begrip godsdiens besig hou nie, en as teologie wesenlik van filosofie verskil, rys die vraag of die begrippe "godsdiens" en "filosofie" in die naam van hierdie vak nie grotendeels as oortollige ornamente oorgebly het nie. Brunner het iets hiervan aangevoel en wou dan ook van godsdiensfilosofie slegs in ,oneintlike" sin praat. Later praat hy van „Formele Teologie" of van „Eristiese Teologie". Ondanks die geregverdigde bedenkings wat teen die naam "Godsdiensfilosofie" mag bestaan, wil ons hierdie benaming nogtans handhaaf, maar dan nie in die 19de eeuse betekenis van filosofiese besinning op die godsdiens as universeel-menslike verskynsel nie, maar as daardie vak van die teologie waar volgens Brunner die gesprek met godsdiens en filosofie gevoer word. Want die teologie staan nie net in 'n voortdurende maar ook in 'n noodwendige dialoog met godsdiens en filosofie. In die ontmoeting met en verdediging teen die aanslag van die heidense godsdiens en filosofie, het die teologie immers sy historiese ontstaan gehad. Van die begin van sy ontstaan af vergesel godsdiens en wêreldwysheid die christelike kerk op sy weg as vraag na en aanvegting van die waarheid waar die kerk aanspraak op maak. Dis veral die situasie waarri die kerk hom in sy ontstaanstyd bevind het, wat die eerste teologiese arbeid van die kerk vanweë sy sterk apologetiese klem godsdiensfilosofies van aard gemaak het. 'n Teologiese arbeid dus waarin dit primêr om stryd en diskussie met godsdiens en filosofie gegaan het. Formeel is elke godsdiensfilosofiese uit- 
spraak apologeties van aard. Die evangelie val nooit in 'n vakuum nie, maar kom in 'n ruimte wat op een of ander wyse geestelik bepaal is en mense van sekere oortuigings van godsdienstige en wêreldbeskoulike aard lewe. Oral waar die evangelie kom moet vyandskap en teenstand oorwin word, ook en veral binne die kerk. Brunner het gepraat van die moeisame stryd wat die Woord van God ook hier te voer het met die „waansinnig in homself geslote menslike rede". Daarom is apologetiek altyd moontlik en nodig, en die godsdiensfilosofie 'n aktuele vak.

Godsdiensfilosofie is dus wel 'n sinvolle naam, maar dan onder die uitdruklike voorbehoud dat ons daaronder nie 'n poging moet verstaan om op openlike of bedekte wyse as teoloog filosofie te beoefen nie, of as filosoof teologie. As ons van teologiese godsdiensfilosofie praat, wil ons daarmee nie te kenne gee dat die teologie nou 'n soort filosofie geword het nie, al is dit dan ook 'n filosofie van 'n heel besondere orde. Maar as die teologie hom rekenskap gee van sy verhouding tot die filosofiese denke van ' $n$ bepaalde tyd, en veral as die teologie deur so 'n filosofie beïnvloed word, is dit tog heeltemal iets anders as wanneer hy self verval tot en hom oplos in spekulatiewe denke. Lg. was die geval met die godsdiensfilosofie van die ou stempel, eg. is die weg van die nuwere godsdiensfilosofie.

Dit het dus duidelik geword dat daar onderskei moet word tussen twee soorte godsdiensfilosofie: 'n filosofiese en teologiese. Die verskil tussen die twee moet gefundeer word in hulle verskillende uitgangspunte en doelstellings. Die vertrekpunt van die filosofiese godsdiensfilosofie is die natuurlike denke, dus vanaf algemene filosofiese vooronderstellings, en dit word gerig op die godsdiens waarvan die christelike geloof 'n bepaalde uiting is. Al sy uitsprake word gefundeer in die rede-immanente denke. Die teologiese godsdiensfilosofie neem sy uitgangspunt daarenteen in die heilsopenbaring van God soos in Ou en Nuwe Testament betuig en die funderingssamehang vir al sy uitsprake lê juis in die openbaringsgetuienis. Dit gaan hier nie om 'n kombinasie van teologie en filosofie nie, maar om 'n konfrontasie van die twee met mekaar wat sy diepere grond daarin het dat albei gekonfronteer is met die een enige waarheid.

In die Protestantisme staan die verkondiging sentraal. Die kerk het die opdrag tot verkondiging, tot uitleg en toepassing van die Skrifwoord. Omdat die verkondiging in mensewoorde geskied, staan die kerk onder die verpligting om so suiwer en 
duidelik as moontlik te spreek, en moet hy sy eie woord gedurig korrigerend in die lig van Gods Woord gebruik. Om die regte spreke van die kerk te dien, is teologie nodig. Die teologie is die mees praktiese wetenskap wat geheel-en-al gerig word op die praktyk van die kerklike lewe: daar waar kerklik gespreek, gehandel en gedink word. Die vakke wat hulle primêr op die regte spreke en regte handeling rig is die dogmatiek en die teologiese etiek onderskeidelik. Maar ook die godsdiensfilosofie, al lyk dit soms asof hy hom slegs op die vlak van die abstrakbegriplike beweeg, is 'n vak wat nie sonder pastorale bewoënheid is nie. Hy rig hom veral op die denke, op daardie deel van die kerklike lewe wat in aanraking is en gevolglik beinvloed word deur die wysheid van die wêreld, die filosofie. In hierdie wêreld waar filosofies-bepaalde opvattings en allerlei teses van godsdienstige en wêreldbeskoulike aard gevind word, moet die kerk sy woord spreek. In sy gesprek met die godsdiens en wêreldbeskouing gaan dit egter nie om 'n poging om die openbaring in Christus te verrassionaliseer in die waan dat 'n mens met redelike argumente die teenstander van die waarheid van die christelike geloof kan oortuig nie. Om die christelike geloof verstandelik aanvaarbaar te maak, was die groot dwaling van die apologetiek van die vorige eeu. Maar dit is 'n ander saak as daar krities gehandel word met godsdienstige en filosofiese opvattings en uitsprake en daar sodoende getrag word om die aanloop tot die geloofsprong van onnodige hindernisse te suiwer. Op hierdie wyse wil die godsdiensfilosofie ook sy deel bydra om die verstaanbare spreke van die kerk te dien in 'n situasie waar daar besware en bedenkings teen die christelike boodskap bestaan. Veral wil hy deur sy besondere werksaamheid teen die gevaar waak dat die wysheid van die wêreld, wat dwaasheid by God is, nie die dwaasheid van die kruisprediking sal verdring nie. 